Laboratoire d'Hydrobiologie de Mali, a effectué pour le compte de la F.A.O., une mission d'étude de développement de la pêche fluviale au Niger. L'extension de l'enquête de la Nigéria au Mali et à la Guinée sera envisagée.

Monsieur Marc Piault, qui a été l'un des responsables de l'enquête Migrations de la CCTA/CSA, se rendra en I 962 au Ghana pour compléter son enquête urbaine de la ville de Kumasi. En liaison avec Monsieur Rouch, il participera à la mise à jour qualitative de l'enquête 'Migrations'. Il entreprendra aussi l'étude des groupes haoussa occidentaux et en particulier l'étude des groupes de la région de Birni N'Konni. Cette étude, qui complète les travaux de Monsieur Nicolas, sera élargie dans les années suivantes aux autres groupes haoussa occidentaux. Ainsi les Haoussa du Niger, négligés jusqu'alors par les anthropologues, seront étudiés dans leur ensemble.

Monsieur E. Bernus, géographe de l'ORSTOM, se rendra au Niger en septembre 1962 pour y entreprendre une étude à long terme des groupements nomades, Touareg-Bella, et éventuellement Peul nomades, non encore étudiés par Mademoiselle Dupire. Le thème de cette étude portera principalement sur le problème de la 'sédentarisation des nomades'.

Madame C. Odier entreprendra en 1962 la mise à jour des documents de G. de Gironcourt (1908-1909 et I9I 1-I912), qui rapporta de ces missions dans la boucle du Niger un corpus d'estampages d'inscriptions lithiques, où figuraient les stèles de la Nécropole de Bentia, supposé être l'ancienne capitale des Sonrai, Koukya. Il rapporta également 223 manuscrits arabes (originaux et copies) actuellements déposés à la bibliothèque de l'Institut (Académie des Inscriptions et Belles-Lettres). Les premières photocopies de manuscrits ont été envoyées au Niger et des lettrés arabes (en particulier Alfa Mossi du service de l'IFAN) en ont entrepris la traduction. Il s'agit d'un ouvrage de 354 pages sur l'histoire des Sonraï, écrite par un lettré de Zinder (cercle de Tillabéry). Ce manuscrit est vraisemblablement l'un des plus anciens ouvrages connus au Niger à ce jour.

\title{
International Commission of Jurists
}

A Seminar on the Rule of Law in Africa, to which African students are being invited, is being held by the International Commission of Jurists (Geneva, Switzerland) in co-operation with 'Justice', the British Section of the Commission, from 9 to 1 I October, at St. Catharine's, Cumberland Lodge, Windsor Great Park, Berkshire. The Seminar will include talks and discussions on such subjects as fundamental rights and the Rule of Law, new constitutions in Africa and fundamental rights, and the Rule of Law in Africa today. Speakers will include distinguished lawyers and jurists, and participants in the Seminar will contribute to the discussions.

\section{The Fourth Pan-African Congress on Prehistory}

THE papers presented and discussed at the Fourth Pan-African Congress on Prehistory, held at Leopoldville from 22 to 29 August 1959, have recently been published by the Musée Royal de l'Afrique Centrale, Tervuren, under the editorship of Georges Mortelmans and Jacques Nenquin. 'The papers in French, English, and Spanish illustrated with diagrams, photographs, and maps include the following contributions:

The Neolithic Cultures of East Africa

Neolithic Cultures of Ghana

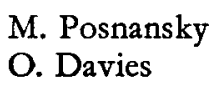

1 Actes du $4^{e}$ Congrès panafricain de préhistoire et de l'étude du quaternaire. Section 3, Pré- et protohistoire. Tervuren: Mus. roy. Afr. centr. (Annales, Sér. in-8, Sci. humaines, 40), 1962. Pp. 5os. 